\title{
Elderly population will increase dramatically
}

\section{Bryan Lincoln}

In 1998, the oldest man in the world passed away in a San Rafael, California, nursing home: he was 115. Asked to what he attributed his long life, Christian Mortensen recommended drinking water, smoking one cigar a day, and lots of singing.

This astonishing person heralds some major increases in the size of the elderly population that will soon occur in California, across the nation and in most countries in the world. The postWorld War II baby boomer's extremely large cohort "hump" is inexorably getting older and will fairly soon start reaching retirement age and beyond. This demographic movement, combined with falling mortality rates at older ages, will cause the number of elderly to rise dramatically into the middle of the 21 st century, both in absolute numbers and as a percentage of the total population.

In addition to various sociological and lifestyle changes, this population tilt raises important questions about how government budgets and public services will respond.

Social Security. In absolute terms, California has the largest number of elderly of any state. At the same time, as a proportion of total population, California has one of the youngest populations among the states, largely due to considerable inflows of immigrants. In 1998, people over 65 made up $11.1 \%$ of California's population (45th in the nation), while those under 18 were $27.7 \%$ of the state's population (7th in the nation) (Statistical Abstract 1998).

The ratio of people aged 65 and older, compared with the working population between 18 and 64 called the "old-age dependency ratio" - is of particular importance to Social Security. Roughly, it measures the proportion of a single retiree's benefits that are financed by a single younger worker. The total dependency ratio for California in 1999 was 0.175 . The 1999 ratios for Hispanics (0.09), Asians $(0.14)$, blacks $(0.125)$ and whites $(0.235)$ demonstrate the importance of immigration for the state's relatively "young" age structure. California's total dependency ratio is expected to grow to 0.32 in 2040, which means that approximately three workers will have to support one elderly person, versus about five workers today (California Department of Finance 1998).

Health care. Many observers consider health care to be an even more pressing problem than Social Security. Because of its high rate of cost growth, health care is expected to strain federal medical-insurance budgets (such as Medicare) much earlier than Social Security. In 1997, total national healthcare expenditures were $13.5 \%$ of gross domestic product (the total income produced within the United States), the highest share for any country in the world.

This amount is split almost exactly in half between public and private funds (National Center for Health Statistics 1999). The rate of growth of medical expenditures slowed somewhat during the decade of the 1990s, from about $8 \%$ to $5 \%$. But this short time-span of cost improvement, along with the extreme complexities of how the health-care market actually works, means health-care costs cannot be considered a problem even remotely close to being solved.

Trying to forecast the future budget of Social Security at current rates of taxes and benefits is somewhat easier than in the health-care sector. The Social Security Administration's official "best" forecast for when the Social Security trust fund will drop to zero is currently 2034 (SSA 1999).

Most experts agree that some type of adjustment must be made to the system. Already under current law, the retirement age will rise to 67 by 2022. One proposal would invest a

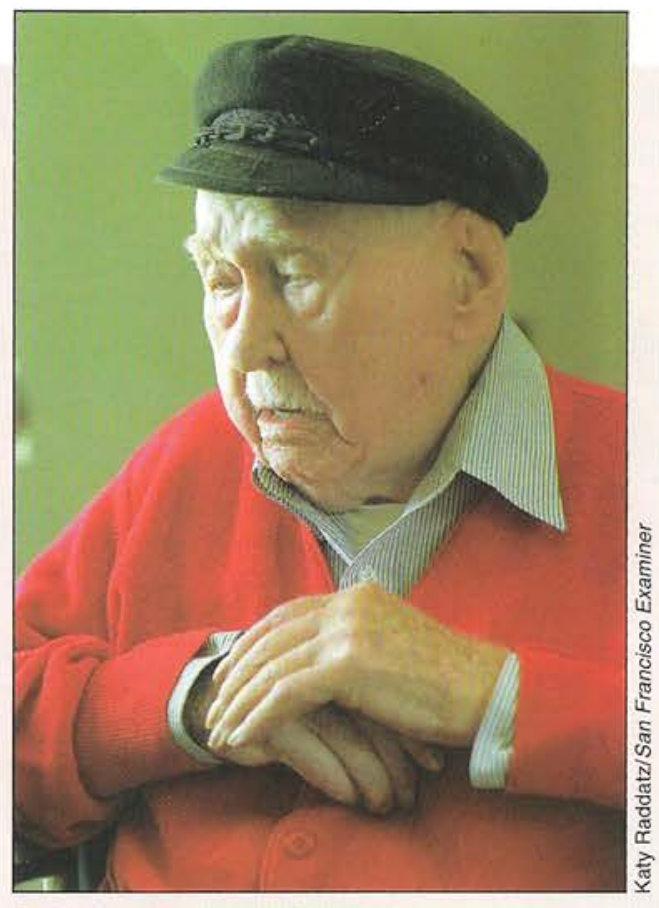

Christian Mortensen in 1997

percentage of the current trust fund surplus in the stock market; a more radical proposal would "privatize" the whole system, making it function more like a pension plan.

There is a consensus view though, that if policy options are limited to simply adjusting payroll taxes upward and lowering benefit schedules, the order of magnitude of changes needed to balance the Social Security budget is between $3 \%$ and $4 \%$. This is relatively modest compared with the challenges faced by other industrialized countries. Though dealing with the coming wave of elderly will require significant adjustments, a view that the sky is falling is perhaps unwarranted.

B. Lincoln is Research Analyst, Center for the Economics and Demography of Aging, UC Berkeley.

\section{References}

California Department of Finance. 1998. Race/Ethnic Population with Age and Sex Detail, 1970-2040. Sacramento. www.dof. ca.gov/newdr/california.txt.

National Center for Health Statistics. 1999. Health, United States, 1999. Hyattsville, MD. www.cdc.gov/nchs/products/ pubs/pubd/hus/hus.htm.

[SSA] Social Security Administration. 1999. Annual report of the board of trustees of the federal OASDI trust funds. www.ssa. gov/OACT/TR/TR99/index.html.

Statistical Abstract of the United States. 1998. www.census.gov/statab/www. 